\title{
PENGARUH PROBIOTIK PADA RESPON IMUN
}

\section{EFFECTS OF PROBIOTICS ON IMMUNE RESPONSE}

\author{
Djoni Djunaedi \\ Laboratorium IImu Penyakit Dalam Fakultas Kedokteran Unibraw / RSU dr. Saiful Anwar Malang
}

\begin{abstract}
Probiotics ("for life") is a live microbial feed supplement or defined as mono- or mixed cultures of live microorganisms which when administered in adequate amounts confer a health benefit to the host by improving its microbial balance. Common descriptives for probiotics include "friendly", "beneficial" or "healthy" bacteria. Under natural conditions a protective gut microflora develops and there is no need for probiotics supplement, but under rather un-natural conditions such like intestinal infections, post antibiotic treatment syndromes, pseudomembranous colitis, the probiotics preparations are needed. The beneficial effects of probiotics in the host are promotion of the gut maturation and integrity, antagonisms against pathogens and immune modulation. Beyond those, the microflora seems to play a significant role in diet induced superinflammation, mucosal immune system, neuroendocrine regulation, immunoglobulin production, macrophages factor restoration, apoptosis stimulation, lymphocyte function modulation, cytokine release, mucin production, intestinal immune homeostasis and inflammation prevention. However, many studies proved that probiotics have "upregulation and downregulation" effects on immune system of the host. This review article will summarize the increasing scientific attention to mechanisms of the immune response of the host towards different components of the microflora and suggest a potential role for selected probiotic bacteria in the regulation of intestinal inflammation and other diseases. Although many clinical studies with probiotics daily products demonstrating positive therapeutic effect, there is still a core question: "how regular consumption of probiotics will affect the health and the risk of infection of healthy consumers", cannot be answered at this point in time. Longterms, prospective studies are still needed.
\end{abstract}

Key words: probiotics, intestinal microflora, immune response

\section{PENDAHULUAN}

Sel-sel yang membatasi saluran gastrointestinal mempunyai suatu sistem detektor yang kompleks yang mampu mengidentifikasi bakteri asing dan berperan sebagai mekanisme pertahanan pertama dalam menghadapi serangan mikro-organisme yang masuk melalui makanan dan minuman yang ditelan oleh individu yang bersangkutan. Sekali tergugah akan terjadi serangkaian peristiwa metabolik yang memproduksi sel dan bahan khemikal (respons imun) yang sangat poten untuk membunuh bakteri asing tersebut dan menjaga individu yang bersangkutan untuk tetap dalam kondisi sehat $(1,2)$.

Dalam saluran gastrointestinal juga ditemukan sejumlah besar mikro-organisme (mikroflora) yang dalam keadaan eubiosis (status seimbang antar populasi bakteri di dalam saluran gastrointestinal) mampu menjalankan berbagai fungsi penting yang bermuara pada menjaga kesehatan tubuh secara keseluruhan. Namun dalam kondisi dysbiosis (kondisi ketidakseimbangan antar populasi

Jurnal Kedokteran Brawijaya, Vol. XXIII, No. 1, April 2007 Korespondensi: Djoni Djunaedi; Laboratorium IImu Penyakit Dalam FK Unibraw/ RSU dr. Saiful Anwar Malang; Jl. Jaksa Agung Duprapto No. 2 Malang; 0341-357663 mikroflora dalam saluran gastrointestinal, kondisi disfungsi mikroflora gastrointestinal), mikroflora tersebut dapat menyebabkan munculnya berbagai gangguan kesehatan (3). Ini berarti, agar tetap sehat maka keseimbangan populasi mikroflora gastrointestinal harus terjaga.

Temuan dari sejumlah besar penelitian menunjukkan adanya hubungan antara penggunaan probiotik dan perbaikan gejala klinik seperti diare, irritable bowel syndrome, penyakit inflamasi usus, kanker, sistem imun yang tertekan, hiperlipidemia, dan penyakit hati (4). Juga ditemukan sejumlah laporan mengenai khasiat probiotik dalam mencegah terjadinya AAD (Antibiotic-Associated Diarrhea) $(5,6,7,8,9,10)$. Salah satu cara kerja probiotik adalah melalui perannya terhadap sistem imun - mengenhance respons inang terutama yang berkaitan dengan peningkatan kerja makrofag dan pelepasan antibodi (11). Bagaimanapun juga sejumlah temuan penelitian lain juga membuktikan bahwa selain pengaruh "upregulation" terhadap sistem imun, probiotik juga mempunyai pengaruh "down-regulation" terhadap sistem imun. Oleh karena itu tingkat keamanan dan kemanfaatan pemberian suatu galur probiotik tidak dapat digeneralisasikan kepada semua kasus. Sehubungan dengan terjadinya peningkatan perhatian ilmiah terhadap kinerja dan manfaat probiotik 
maka tulisan ini bertujuan untuk merangkum berbagai artikel mengenai jenis, cara kerja dan pengaruh probiotik pada berbagai kondisi gengguan kesehatan.

\section{Definisi}

Ketika awal diperkenalkan, probiotik dimaknai sebagai makanan tambahan (food supplements) yang bermanfaat untuk memperbaiki kesehatan seseorang dan didefinisikan sebagai suatu mikro-organisme dan substansi yang bertujuan memperbaiki keseimbangan mikro-organisme dalam usus. Pada perkembangan selanjutnya, probiotik didefinisikan sebagai mikro-organisme hidup dalam bentuk makanan tambahan yang memberikan keuntungan melalui kemampuan memodulasi mukosa, aktivitas imun sistemik dan fungsi epitel (12,13). FAO (the Food Agriculture Organization) dan WHO (World Health Organization) mendefinisikan probiotik sebagai mikro-organisme hidup yang apabila diberikan dalam jumlah cukup bermanfaat memperbaiki kesehatan inang (4).

\section{Cara kerja probiotik:}

\section{Produksi bahan-bahan anti-mikrobial}

Produk probiotik menekan jumlah, metabolisme dan produksi toksin oleh bakteri usus. Temuan penelitian menunjukkan bahwa pemberian probiotik pada tikus tidak berhasil mengeliminasi Clostridium difficile namun dapat mencegah timbulnya kolitis dan mungkin juga menekan produksi toksin bakteri tersebut. Selain itu ditemukan bahwa volatile fatty acids yang diproduksi oleh Lactic Acid Bacteria (LAB) mampu mengendalikan kolonisasi Shigella sonnei dan Entero Pathogenic Echeriecia Coli (EPEC) $(14,15)$.

2. Kompetisi pada reseptor adhesi

Bakteri patogen harus mempunyai kemampuan untuk melakukan adesi sehingga dapat menghasilkan kolonisasi dan menimbulkan penyakit. Temuan penelitian menunjukkan bahwa hewan coba yang diberi galur $E$. coli non-patogen lebih resisten terhadap infeksi $E$. coli patogen dibandingkan dengan kontrol. Selain itu juga dilaporkan bahwa pemberian probiotik mampu mencegah tikus dalam status imunodefisiensi dari serangan candidiasis dan pemberian heat-killed $L$. acidophilus (lacteol strain) mampu menghambat adesi $E$. coli pada dinding usus penderita (in vivo) maupun pada media in vitro (14,16-19). Laporan lain menunjukkan bahwa pemberian heat-killed $L$. acidophilus kepada penderita diare anak yang memperoleh terapi rehidrasi oral dan antibiotik bermuara pada durasi diare yang lebih pendek dibandingkan dengan mereka yang diberi plasebo (20). Ini berarti galur non-patogen juga terikat pada reseptor adesi yang sama dengan galur patogen sehingga galur patogen tidak mempunyai kesempatan untuk melakukan adesi, membentuk kolonisasi dan menimbulkan penyakit $(15,21)$. Probiotik nampaknya berperan sebagai pesaing (competitor) bagi galur patogen untuk mengikatkan diri pada reseptor adesi sehingga galur patogen tak mampu membentuk koloni dan dengan demikian tidak mampu menimbulkan penyakit.

\section{Kompetisi terhadap zat makanan}

Meskipun usus merupakan sumber makanan yang berlimpah sehingga teori mengenai persaingan antar mikroorganisme nampaknya tidak dapat diterima, namun perlu diingat bahwa keberlangsungan mekanisme persaingan dengan mikro-organisme patogen hanya memerlukan pelibatan satu jenis nutrient. Temuan penelitian in vitro menunjukkan mikro-organisme usus dalam bentuk koloni bersaing secara lebih efisien terhadap $C$. difficile berkaitan dengan monomeric glucose, $\mathrm{N}$-acetyl-glucosamine dan asam salisilat $(14,21)$.

\section{Stimulasi imunitas}

Cara kerja bakteria probiotik dalam mendesak pertumbuhan bakteri penyebab penyakit nampaknya diawali dari pengaruh kerjanya terhadap sistem imun. Pada dekade belakangan ditemukan bahwa lactobacilli yang dimakan dapat menstimulasi aktivitas makrofag terhadap beberapa spesies bakteri yang berbeda. Hal tersebut mungkin disebabkan oleh absorbsi antigen atau translokasi lactobacilli melalui dinding usus langsung ke peredaran darah untuk kemudian menstimulasi makrofag. Penelitian membuktikan bahwa lactobacilli yang disuntikkan intravena ditemukan hidup dalam hati, limpa dan paru disertai aktivitas NK cell yang meningkat $(14,15,21)$.

\section{Pengaruh probiotik pada sistem imun}

\section{Sistem imun dalam usus.}

Sekitar $80 \%$ dari total sel yang memproduksi imunoglobulin dalam tubuh manusia berada dalam lamina propria usus. Enterosit (intestinal epithelial cells, IEC) merupakan sel imunokompeten yang berperan pada berbagai reaksi lokal terhadap mikro-organisme patogen (22). Interaksi enterosit dengan faktor-faktor sekitar selain mengaktivasi proses enzimatik terhadap antigen makanan juga mengaktivasi ekspresi molekul adesi, MHC kelas I dan II, presentasi antigen terhadap limfosit, produksi sitokin, transportasi slg (secretory immunoglobulins) dan kompleks imun dengan slgA (22). Sel imunokompeten yang lain adalah makrofag dan sel dendrit yang memegang peran penting dalam melindungi tubuh terhadap antigen di tingkat mukosa. Ini berarti, sistem imun seluler yang teraktivasi oleh kehadiran mikro-organisme probiotik akan meningkatkan produksi $\lg A$ (imunoglobulin $A$ ) yang berperan pada sistem imun mukosa. Sintesis IgA tergantung pada sel $T$ dan sitokin yang diproduksi oleh limfosit yang teraktivasi $(22,23)$.

Faktor yang mempengaruhi kerja limfosit dan produksi imunoglobulin yang bertanggungjawab terhadap timbulnya penyakit antara lain adalah nutrisi, aktivitas fisik, tidur, emosi, umur, jenis kelamin, ritme sirkadian, temperatur tubuh, obat-obatan dan penyakit yang sedang diderita (22). Laporan penelitian dalam sejumlah literatur mengemukakan 
adanya hubungan antara perbaikan nafsu makan, pola tidur, emosi dan ritme sirkadian dengan pemberian premaupun pro- biotik. Nampaknya hal tersebut diperankan oleh kerja produk metabolit yang dihasilkan dari proses fermentasi mikro-organisme dalam usus. Dilaporkan bahwa penderita defisiensi laktase memiliki toleransi yang lebih baik pada laktose dalam yoghurt dibandingkan laktose dalam susu. Nampaknya yoghurt memproduksi enzim laktase yang membantu mencernakan laktose. Berbagai tingkat toleransi yang berbeda ditemukan pada penelitian dengan pemberian berbagai galur lactobacillus. Juga dilaporkan bahwa pemberian yoghurt kepada anak yang mengalami infeksi Giardia lamblia dapat memperbaiki aktivitas laktase dalam usus. Pemberian LAB juga secara signifikan dapat menurunkan konsentrasi toksin (seperti endotoksin) dalam serum (24).

2. Regulasi neuroendokrin pada respons fase akut.

Stresor bekerja mempengaruhi fungsi imun dan respons inflamasi melalui sistem syaraf simpatis dan aksis HPA (hypothalamic-pituitary-adrenal axis) (23). Stresor akut secara umum menstimulasi imunitas sedangkan stresor kronis (seperti lingkungan, sosial, fisiologis, pola dan jenis makanan) mengakibatkan down-regulation sistem imun (25). Homeostasis pada epitel usus dan proteksi terhadap kerusakan epitel diatur oleh sistem signal TLR ("Toll Like Receptor") yang diperankan oleh mikro-organisme komensal usus. Nampaknya TLR juga menginduksi produksi faktor "repair". TLR diaktivasi oleh adanya molekul-molekul LPS (lipopolysacharide), flagelin dan lipoteichoic acid melalui jalur intracellular signaling yang selanjutnya mengaktivasi transkripsi nuclear factor kB (NF-kB). Diduga efek inhibisi ("down regulation") jalur NF-kB yang mempunyai potensi anti-inflamasi berperan dalam mengatur proses inflamasi dalam usus (26).

Nutrisi enteral (NE) memegang peran penting dalam mengontrol reaksi fase akut dan respons imun di samping sebagai pemasok kalori. Temuan penelitian menunjukkan adanya peningkatan parameter imun seperti aktivitas sel NK (natural killer), jumlah limfosit, respons terhadap PHA (phytohemagglutinin) pada kelompok yang memperoleh nutrisi enteral (kelompok NE) dibandingkan dengan kelompok yang memperoleh nutrisi parenteral (kelompok NP). Secara klinis, kelompok NE juga menunjukkan perbaikan dalam kasus seperti SIRS (systemic inflammatory response syndrome), sepsis, MOF (multi organs failure) dan durasi rawat di ICU (intensive care unit) $(26,27)$.

Konsumsi asam lemak jenuh terbukti mempengaruhi respons imun, menghambat fungsi makrofag dan lebih mengaktivasi respons Th2 dibandingkan dengan respons Th1. Dilaporkan bahwa pemberian probiotik dapat membantu menurunkan kolesterol melalui peningkatan aktivitas hidrolase garam empedu yang diikuti oleh peningkatan ekskresi kolesterol $(4,28)$. Selain itu, temuan penelitian in vitro dengan stimulasi LPS (lipopolysacharide) terhadap makrofag peritoneum menunjukkan peningkatan signifikan II-6 (interleukin-6), TNFa (tumor necrosis factor alpha) dan $\mathrm{PGE}_{2}$ (prostaglandin E2) pada kelompok diet tinggi lemak.

Jelas akut seperti luka bakar, syok, perdarahan, iskemia dan trauma terbukti meningkatkan permeabilitas usus dan translokasi bakteri. Selama kondisi tersebut belum dapat diatasi, usus merupakan sumber utama penyebab sepsis sebab lumen usus mengandung banyak bakteri yang potensial menjadi patogen dan toksik. Laporan penelitian menunjukkan bahwa pemberian probiotik dapat memperbaiki kondisi pasien secara umum melalui peningkatan kekuatan barier usus dan pengurangan translokasi bakteri dengan memanipulasi mikro-ekosistem. Selain itu peningkatan populasi sel penghasil IgA juga memperbaiki gangguan transportasi makro-molekuler dan membantu degradasi antigen oleh mukosa sehingga dapat mencegah terjadinya MOF. Dilaporkan bahwa pemberian lactobacillus dan oat fibers (kombinasi pro- dan pre- biotik) kepada 5 pasien yang sedang dirawat di ICU dengan indikasi MOF pasca tindakan operasi gastrointestinal, menunjukkan keberhasilan penyembuhan yang menakjubkan (22).

\section{Peran $L A B$ dalam mekanisme sistem imun}

In vitro telah dibuktikan kemampuan bifidobacteria dalam menginduksi secara signifikan produksi $\lg \mathrm{A}$ oleh Peyer's patches. Di antara 120 galur bifidobacteria yang telah dikenal, hanya 3 galur saja yang mampu menginduksi produksi $\lg A$ dan 2 di antaranya adalah $B$. breve dan $B$. longum. Selain itu, juga dilaporkan bahwa Lactobacillus $G G$ mampu meningkatkan secara signifikan respons imun $\lg A$ pada Crohn's disease dan infeksi rotavirus, sedangkan $L$. acidophilus mampu meningkatkan produksi IgA sebanyak $4 \mathrm{x}$ lipat pada stimulasi oleh Salmonella typhi. Terbukti bahwa $B$. longum dan $L$. acidophilus secara signifikan meningkatkan daya fagosit terhadap Salmonella, namun tidak demikian halnya dengan $L$. fermentum, sementara $L$. casei terbukti meningkatkan aktivitas makrofag pada percobaan intraperitoneal tikus (21).

Uji coba 4 jenis probiotik kepada hewan coba memberikan hasil yang menarik, yaitu: L.acidophilus meningkatkan proliferasi limfosit hingga $43 \%$, sedangkan $L$. casei (yakult), L. gasseri, dan L. thamnosis menghambat proliferasi basal (14-51\%) dan mitogen-stimulated oleh mitogen concanavalin A (43-68\%) dan oleh LPS (23-63\%). Berbagai temuan penelitian juga menunjukkan kemampuan Lactobacillus species dalam menstimulasi produksi IFNy (interferon gamma) dan IL-12 yang selanjutnya meningkatkan peran Th1-type response dan memperbaiki keseimbangan Th1-Th2 (29). Temuan lain menunjukkan bahwa pemberian probiotik $L$. rhamnosus $G G$ menurunkan kejadian "atopic eczema" dan alergi makanan. Nampaknya selain efek "down regulating inflammation" yang berhubungan dengan kejadian reaksi hipersensitivitas, juga terjadi efek 
"upregulate anti-inflammtory cytokines" seperti IL-4 dan IL10 pada kasus atopik anak $(27,30,31)$. Bertolak dari berbagai temuan penelitian sebagaimana diuraikan tersebut, nampak bahwa galur LAB mempunyai efek imun yang berbeda dan bahwa berbagai uji coba tersebut tidak dapat diekstrapolasi dari satu galur ke galur yang lain meskipun masing-masing galur tersebut berikatan sangat erat.

Pemberian $L A B$ cendrung menentukan arah respons imun humoral yang bervariasi antar galur LAB. Selain itu, pemberian LAB juga mempengaruhi ekspresi sitokin sejalan dengan variasi antar galur. Contoh: pada manusia, LAB golongan bakteri yoghurt yang meningkatkan aktivitas ekspresi sitokin (TNFa, IFNy dan IL-1 $\beta$ ) pada sel mononuklear dibandingkan dengan kontrol adalah $L$. bulgaricus dan $S$. thermophilus baik secara individual maupun secara bersama. Sedangkan jenis LAB yang paling kuat dalam menstimulasi makrofag adalah $S$. thermophilus jika dibandingkan dengan $B$. adeloscentris dan $B$. bifidum. Selain itu, heat-killed $L$. acidophilus juga meningkatkan ekspresi IL-1a (300\%) dan TNFa (1000\%) pada makrofag tikus dibandingkan dengan galur lain lactobacillus dan bifidobacteria. Mekanisme bakteri nonpatogen termasuk golongan LAB dalam mencegah beberapa jenis infeksi nampaknya berlangsung melalui pelepasan bacteriokines (cytokine like molecules), NO, radikal bebas, $\mathrm{pH}$ rendah, receptor blocking, dan penghambatan adesi sel epitel dengan bantuan musin intestinal.

Bertolak dari cara kerja probiotik sebagaimana diuraikan di depan, nampaknya penelitian penggunaan probiotik sebagai profilaksis lebih perlu dikerjakan daripada penelitian penggunaan probiotik untuk pengobatan sebab probiotik diformulasikan tidak untuk menggantikan peran antibiotik melainkan untuk memperbaiki defisiensi flora akibat diet dan stres lingkungan. Probiotik mendorong inang lebih resisten terhadap penyakit dan mengurangi frekuensi penggunaan antibiotik. Gabungan antara probiotik dan prebiotik (disebut sinbiotik) menunjukkan kemampuan seperti antibiotik dalam hal mengontrol infeksi di daerah colon. Penggunaan Eco immunonutrition yang menawarkan pre-, pro- dan sinbiotik bermuara pada rawat tinggal yang lebih pendek bagi penderita di ICU sehingga preparat ini merupakan pilihan utama nutrisi oral-enteral (22). Temuan lain menunjukkan bahwa pemberian synbiotics pada penderita hepatitis B fase akut meningkatkan IFNy dan IL12, menurunkan SGOT, SGPT, GLDH, gamma GT dan bilirubin secara signifikan (32).

Temuan penelitian in vitro menunjukkan bahwa probiotik meningkatkan respons imun spesifik maupun nonspesifik dengan cara meregulasi makrofag, meningkatkan jumlah sitokin, sel NK dan kadar imunoglobulin. Pemberian L. plantarum 299v kepada anak yang menderita infeksi HIV disertai episode diare dan malabsorbsi terbukti menunjukkan peningkatan respons imun. Ini berarti, L. plantarum 299v dapat diberikan dengan aman terhadap "immunocompromised host". Respons imun tersebut nampak lebih meningkat apabila diberikan kombinasi Lactobacillus dan Bifidobacteria (33).

\section{Preparat probiotik}

Preparat probiotik yang beredar di pasaran terutama dari golongan LAB seperti lactobacilli, streptococci, dan bifidobacteria yang juga merupakan komponen mikroflora gastrointestinal dan relatif tidak memberikan pengaruh merugikan. Kemasan probiotik dapat mengandung satu atau beberapa galur bakteri yang berbeda. Galur LAB seperti Lactobacillus acidophilus, L. casei, L. gasseri, Enterococcus faecium dan Bifidobacterium bifidum yang dipakai dalam probiotik terutama diisolasi dari intestinal. Penggunaan non-human derived organisms dalam yoghurt (yoghurt starter bacteria) antara lain L. bulgaricus dan Streptococcus thermophilus juga memberikan perbaikan di bidang kesehatan meskipun kemampuan bakteri yoghurt untuk membentuk koloni dalam usus sangat diragukan $(11,21)$. Beberapa peneliti di USA membuktikan adanya penurunan secara signifikan aktivitas enzim bakteri seperti glucuronidase, nitroreductase dan azoreductase dengan pemberian $L$. acidophilus. Nampak bahwa aktivitas enzimenzim tersebut menurun selama lactobacillus supplement dikonsumsi untuk kemudian aktivitas enzim berangsurangsur pulih kembali seperti semula apabila pemberian lactobacillus supplement dihentikan $(24,27,29)$.

Sejumlah industri farmasi telah memproduksi dan memasarkan probiotik dengan tujuan yang sama yaitu meningkatan kualitas hidup manusia. Berbagai kombinasi bakteri dengan mineral, vitamin dan prebiotik telah beredar di pasaran baik sebagai kemasan bebas maupun sebagai kemasan yang diresepkan. Untuk mencegah timbulnya reaksi yang mengurangi bahkan menghilangkan tujuan kombinasi (bakteri, vitamin dan mineral) nampaknya diperlukan proses pelapisan masing-masing bahan tersebut dengan bahan pelapis yang tahan terhadap asam lambung. Kelebihan kemasan semacam ini adalah jumlah bakteri hidup yang sampai ke usus tetap terjamin dalam jumlah besar, tidak memerlukan penyimpanan khusus, bebas kalori, tanpa rasa dan praktis. Sedangkan makanan probiotik umumnya tidak stabil, membutuhkan penyimpanan khusus, dibatasi masa kadaluarsa, dosis rendah vitamin dan mineral, mengandung kalori dan memiliki rasa khas (29).

\section{Kondisi yang membutuhkan konsumsi probiotik}

1. Chronic bowel problems atau adanya infeksi berkepanjangan seperti candidiasis

2. Sebagai prevensi terhadap keracunan makanan ketika sedang berwisata (bifidobacteria dan acidophillus mampu membunuh sebagian besar food poisoning bacteria)

3. Wanita dalam status premenopause dan menopause untuk mereduksi osteoporosis, individu dengan 
hiperkholesterolemia, individu dengan masalah kesehatan kronis (seperti acne, masalah kulit, alergi, artritis, kanker), individu yang memperoleh pengobatan radiasi, individu dengan infeksi vagina atau saluran kemih berulang

Bagaimanapun juga, pemberian atau konsumsi probiotik dianjurkan di bawah pengawasan tenaga profesional (dokter) (34).

\section{PENUTUP}

1. Probiotik adalah mikro-organisme hidup yang memberikan keuntungan dengan cara memperbaiki keseimbangan mikro-organisme usus dan aktivitasnya dapat mempertahankan keutuhan "membran mukosa usus"

2. Cara kerja probiotik berlangsung melalui mekanisme produksi bahan anti-mikrobial, kompetisi pada reseptor adhesi, kompetisi zat makanan dan stimulasi imunitas (menginduksi produksi lgA, mengontrol reaksi fase akut, meningkatkan peran Th1-type response) dalam kadar yang seimbang

3. Meskipun pemberian probiotik pada umumnya aman, namun pemberian preparat tersebut kepada pasien dengan sepsis berat harus dilakukan secara hati-hati
4. Temuan penelitian klinis menunjukkan bahwa keberhasilan (efek positif) pemberian suatu galur probiotik pada situasi tertentu tidak dapat digeneralisasi pada galur lain ataupun pada populasi yang berbeda

5. Preparat probiotik yang beredar di pasaran terdiri dari berbagai kombinasi bakteri terutama kombinasi lactobacilli dan bifidobacteria dengan berbagai jenis vitamin dan mineral

6. Kemasan yang menjamin ketercapaian manfaat maksimal (tujuan) kombinasi probiotik-vitamin-mineral adalah kemasan yang menggunakan konsep inovatif 3 lapis dari bahan selaput salut enterik

7. Masih diperlukan usaha besar dan waktu yang panjang untuk meneliti spesies (galur) probiotik yang memiliki tingkat keamanan tinggi dan bermanfaat terhadap kesehatan manusia pada umumnya.

Probiotik dianjurkan diberikan kepada mereka yang mengalami penyakit kronis dan/atau berulang, sedang memperoleh pengobatan radiasi, kondisi premenopause dan menopause, sedang bepergian (melakukan perjalanan).

\section{DAFTAR KEPUSTAKAAN}

1. Farnworth E. Food to Stimulate The Immune System. www.medicinalfoodnews.com/vol08/issue3/immunity. diakses tanggal 20 Agustus 2004

2. Chin J, Turner B, Barchia I, Mullbacher A. Immune response to orally consumed antigens and probiotic bacteria. Immunol Cell Biol. 2000;78(1): 55-66

3. Rolfe RD. The Role of Probiotic Cultures In The Control Of Gastrointestinal Health. J of Nutr 2000; 130:S396-402

4. Brown AC, Valiere A. Probiotics and medical nutrition therapy. Nutrition in Clinical Care 2004; 7(2):56-68

5. Broussard EK, Surawicz CM. Probiotics and Prebiotics in Clinical Practice. Nutrition in Clinical Care 2004; 7(3):104-113

6. Goossens DJ, Jonker D, Stobberingh E, et.al. Probiotics in Gastroenterology: Indications and Future Perspectives. Scandinavian Journal of Gastroenterology - Supplement 2003; 239:15-23

7. Gotz V, Romankiewicz JA, Moss J, et.al. Prophylaxis against Ampicillin-Associated Diarrhea with a Lactobacillus Preparation. American Journal of Hospital Pharmacy 1979; 36:754-756

8. Marignani M, Angeletti S, Fave GD. Acute Infectious Diarrhea. N Engl J Med 2004;350(15):1576-1577

9. Meier R, Burri E, Steuerwald M. The Role of Nutrition in Diarrhoea Syndromes. Current Opinion in Clinical Nutrition \& Metabolic Care 2003; 6(5):563-567

10. Sullivan A, Nord CE. Probiotics and Gastrointestinal Diseases. Journal of Internal Medicine 2005; 257(1):78-92

11. Katelaris PH. Probiotic Control of Diarrhoeal Disease. Asia Pacific J Clin Nutr 1996; 5:39-43

12. Fedorack RN, Madsen KL. Probiotics as Modulators of the Gut Flora. Br J Nutr 2004; 88-Suppl 1:S39-49

13. Matsuguchi T, Takagi A, Matsuzaki T, et.al. Lipoteichoic Acids from Lactobacillus Strains Elicit Strong Tumor Necrosis Factor Alpha-Inducing Activities in Macrophages through Toll-Like Receptor 2. Clinical \& Diagnostic Laboratory Immunology 2003; 10(2):259-266

14. Coconnier MH, Bernet MF, Chauviere G. Adhering Heat-Killed Human Lactobacillus Acidophilus, Strain LB, Inhibits the Process of Pathogenicity of Diarrhoeagenic Bacteria in Cultured Human Intestinal Cells. J Diarrhoeal Dis Res 1993; 11(4):235-242

15. Fooks LJ, Gibson GR. Probiotics as Modulators of the Gut Flora. Br J Nutr 2002; 88-Suppl 1:S39-49

16. Chauviere G, Conconier MH, Kerners S, et.al. Competitive Exclusion of Diarrheagenic Escherichia coli (ETEC) from Human Enterocyte-Like Caco-2 Cells by Heat-Killed Lactobacillus. FEMS Microbiology Letters. 1992; 91:213-218

17. Fourniat J. Heat-killed Lactobacillus acidophilus inhibits adhesion of Escherichia coli B41 to HeLa cells. Ann Rech Vet. 1992; 23:361-370 
18. Wagner RD, Pierson C, Warner T, et.al. Probiotic effects of feeding heat-killed Lactobacillus acidophilus and Lactobacillus casei to Candida albicans-colonized immunodeficient mice. Journal of Food Protection 2000; 63(5):638644

19. Xiao SD, Zhang Z, Lu H, et.al. Multicenter, randomized, controlled trial of heat-killed Lactobacillus acidophilus LB in patients with chronic diarrhea. Advances in Therapy 2003;20(5):253-260

20. Simakachorn N. Clinical evaluation of the addition of lyophilized, heat-killed lactobcillus acidophilus $L B$ to oral rehydration therapy in the treatment of acute diarrhea in children. J Pediatr Gastroenterol Nutr 2000;30(1):68-72

21. Fuller R. Probiotics in Human Medicine. Gut. 1991; 32:439-442

22. Herich R, Levkut M. Lactic acid bacteria, prbiotics and immune system. Vet.Med 2002; 47(6):169-180

23. Bertini R, Bianci M, Ghezzi P. Adrenalectomy sensitizes mice to lethal effects of interleukin-1 and tumor-necrosis factor. J Exp Med 1988; 167:1702-1712

24. Bengmark S, Lorenzo G, Culebras JM. Use of pro-, pre- and synbiotics in the ICU: future options. Nutr Hosp 2001; 16(6):239-256

25. Olff M. Stress, depression and immunity: the role of defense and copying styles. Psychiatry Res 1999; 85:7-15

26. Hooper LV, Wong MH, Thelin A, et.al. Molecular analysis of commensal host-microbial relationships in the intestine. Science $2001 ; 291: 881-884$

27. Boyle RJ, Robins-Browne RM, Tang MLK. Probiotic use in clinical practice: what are the risk? Am J Clin Nutr 2006; 83:1256-1264

28. deRoos NM, Katan MB. Effects of probiotic bacteria on diarrhea, lipid metabolism, and carcinogenesis: a review of papers published between 1988 and 1998. Am J Clin Nutr 2000;71:405-411

29. Parvez S, Malik KA, Kang SA, Kim HY. Probiotics and their fermented food products are beneficial for health. Journal of Applied Microbiology 2006; 100:1171-1185

30. Haghighi HR, Gong J, Gyles CL, et.al. Modulation of antibody-mediated immune response by probiotics in chickens. Clinical and Diagnostic Laboratory Immunology 2005; 12(12):1387-1392

31. Mohamadzadeh M, Olson S, Kalina WV, Ruthel G, Demmin GL, Warfield KL, Bavari S, Klaenhammer TR. Lactobacilli antivate human dendritic cells that skew T cells toward T helper 1 polarization. Proceedings of the National Academy of Sciences of the USA 2005;102(8):2880-2885

32. Trihadi $D$, Harjalukita R. The effect of synbiotic treatment with interferon-gamma, interleukin-12 in acute hepatitis $B$. FK UNDIP. 2004

33. Cunningham-Ryndles S, Ahrne S, Bengmark S, et.al. Probiotics and immune response. Am J Gastroenterol 2000; 95:S22-S25

34. Anonynmous. Antibiotics, probiotics and the gut flora. http://www.liferesearchuniversal.com/probiotics. diakses tanggal 20 Agustus 2004. 